\title{
What do festinos at a national arts festival regard as value for money?
}

\author{
E. du Plessis*, E. Slabbert and M. Saayman \\ North-West University, TREES (Tourism, Research in Economic Environs and Society), \\ NWU (Potchefstroom Campus), Hoffman Street, Private Bag X6001, Potchefstroom 2520, South Africa
}

*To whom all correspondence should be addressed

lindie.duplessis@nwu.ac.za

\begin{abstract}
This research attempts to provide guidelines for the management of the Klein Karoo National Arts Festival by determining factors and identifying the determinants of value for money for this unique tourism product. A survey was conducted during the duration of the festival that was held from 31 March 2012 to 7 April 2012. Seven hundred questionnaires were distributed while 600 completed questionnaires were returned. Statistical analysis consisted of three stages: descriptive statistics to analyse the socio-demographic profile of respondents; after which a factor analysis, focusing on factors influencing value for money perceptions, and a regression analysis were performed. Four factors were identified: experience, amenities, quality and price and event attributes. Of these, it was found that event attributes is the premier factor contributing to value for money at a festival. This study could add to the body of knowledge regarding the travel behaviour of visitors as well as pinpointing what festival attendees perceive as value for money. Consequently, this article can be used to assist managers in providing value for money and in obtaining a competitive advantage in the industry by revising management structures and marketing campaigns.
\end{abstract}

\section{Introduction and background}

Given the recent global financial crisis, tourists tend to overanalyse the value they derive from purchases. Decisions on how to obtain or receive value for money are a daily reality and tourists are now constantly making selections regarding which items or services to purchase (Khan, 2011; Singh, 2011; Erlendsson, 2002). The perception of whether or not one receives value for money could be influenced by a number of factors, such as quality, price, cleanliness of facilities, infrastructure and facilities, entertainment and variety of products, to name but a few (Du Plessis \& Saayman, 2015:6; Sweeney \& Soutar, 2001:203; Cant, 2005:6). The debate concerning which factors bring the greatest influence to bear on this perception is affected by the complex nature of the concept of value for money, which may differ from person to person, event to event and from industry to industry (Du Plessis \& Saayman, 2015).

Literature contributes to this debate by articulating the various views held regarding value for money and the number of factors identified in different scenarios (Du Plessis \& Saayman, 2015; Seymour, 2012; Cronin, Brady \& Hult, 2000; Kainth \& Verna, 2011; Yang \& Peterson, 2004; Tait, 2009). It is, however, agreed that value for money equals quality and price and that these two factors exert the greatest influence on the perception of receiving such value (Weaver, Weber \& McCleary, 2007:334; Lovelock, 2000:41; Cant, 2005:6; Sweeney \& Soutar, 2001:203; Du Plessis \& Saayman, 2015:15). Consequently, on examining the literature, there is still no consensus concerning which of these factors exercises the greatest influence or what the influences or determinants that influence these perceptions are. Nonetheless it is clear that researchers agree that identifying these factors and the determinants of these factors could add to the success of management in promoting tourism products.

It is evident from the literature that tourist perceptions of value differ and demographic profiles could additionally have an impact on these ideas. Huang and Yang (2011:2) undertook research on measuring rural tourism value for money and found that a tourist who has a more substantial income is more likely to travel, consequently enjoying more exposure to a greater number of experiences. Due to his/her wider experience he/she will have higher expectations. In addition, Bowman and Ambrosini (2000:2) state that economists have a tendency to refer to the utility theory as well as to the concept of marginal utility. This theory primarily states that the consumer, the tourist in this case, is likely to spend their income in a way that would maximize the level of satisfaction that they receive from the product or service.

Knowledge on the travel behaviour of different tourists to tourism destinations could assist managers in planning for what, where and how to successfully market and develop successful events (Saayman, 2003; Chan \& Baum, 2007). Further insights into the demographic characteristics of tourists regarding festivals and events could benefit the marketers, specifically with regard to market segmentation, product development, service quality evaluation, image development and promotional activities (Fodness, 1994; Kozak, 2002; Yoon \& Uysal, 2005). 
Although the profile of the festival attendees (festino defined by Saayman and Saayman, (2006) as a festival goer) has received research attention, there is a lack of information which focuses on how the demographic profile of these attendees influences their perception of value for money. In order to market festivals more effectively, it is consequently essential to generate more specific knowledge about visitors and their perceptions of value in order to manage certain factors that would add to the satisfaction of tourists and ensure repeat visits (Yoon \& Uysal, 2005; Chan \& Baum, 2007). Repeat visits from festival attendees in the South African festival environment are becoming more and more important each year owing to the increasing competition between South African festivals as well as to sustain the growth of the said festivals. Therefore, the purpose of this research is to determine which factors influence festino's perceptions of value for money at the Klein Karoo National Arts Festival (KKNK).

The KKNK is an annual event over the Easter holiday in the small Karoo town of Oudtshoorn in the Western Cape and is regarded as a very popular arts festival in South Africa (Kruger, Saayman \& Ellis, 2010:80). The original purpose was to offer a festival for Afrikaans speaking people and to furnish the host community with financial rewards (Kitshoff, 2004). The total economic impact of the KKNK is R110 million, which makes the festival a major contributor towards the Oudtshoorn economy (Kruger, Saayman \& Ellis, 2010:80). The KKNK offers a wide range of rock, pop, cabaret, drama and comedy productions that attracts culture lovers from all over and is widespread with over 750 artists and 40 different venues attracting more than 100000 visitors a year (Kruger, 2009:15). However, a problem that has become apparent is that since 2010 there has been a decline in tickets being purchased by visitors to the festival (Erasmus, Saayman, Saayman, Kruger, Viviers, Slabbert \& Oberholzer, 2010:2).

This study could add to the recent literature debate about the importance of quality and price in the perception of value for money. It could furthermore contribute to the body of knowledge regarding value for money within the tourism industry and the influence of demographic characteristics and tourist behaviour concerning these factors. This is important if sustainability is a priority for the management of the KKNK. Hence, it is important for these managers to acknowledge the unique factors identified as value for money based on the views and perceptions of visitors to the festival, if it is their intention that the festival remains sustainable.

\section{Background to the research}

Who decides on value? In the majority of industries the price of a product is explicit, but the value of the product under discussion depends on the personal tastes and priorities of different tourists (Kirkpatrick, 2009:16). It is of course, extremely difficult to measure value, particularly future value, and even when delivered, products or services are intangible, raising the questions of how one quantifies what truly value is, and does this give broad enough consideration to the collective goals of all stakeholders? The dimension of the term value in literature is extremely diverse, but researchers (Chiang \& Jang, 2007:53) agree that consumers describe value as a situation where one receives some kind of benefit. The definition of this benefit changes when looking at it from the perspective of different disciplines and different industries. It would also be influenced by the kind of product and service involved and thereafter obviously the transaction involved, where consumers mostly pay for a certain product or service. The most common definition of value is the ratio or trade-off between quality and price (Cravens, Holland, Lamb \& Moncrieff, 1988; Monroe, 1990), which is a valuefor-money conceptualization. Value may then be determined using the following formula (Cant 2005:6; Sweetney \& Soutar 2001:203): Value=Perceived benefits/Price.

Research conducted by various researchers as indicated in the discussion below highlighted the customer's point of view regarding value and give some insight into factors that contribute to a positive perception towards value for money.

\section{Price}

It is clear from the literature that value is regarded as an affordable price for goods and services (Haarhoff, 2007:411). Price is always a factor and could be considered part of the experience if one takes into account that money is spent on accommodation, food, transport and souvenirs, to name just a few factors (Kainth \& Verma 2011:21; Yang and Peterson 2004:802). Proof of good value for money is in believing or concluding that the goods/services received was worth the price paid (Du Plessis \& Saayman (2015:5).

\section{Quality}

Value is further regarded as the quality one gets for the amount spent on a product or service (Du Plessis \& Saayman, 2015:430). Quality provides satisfaction when customers are of the opinion that they have received or purchase a good product or service (Monroe 1990:46). Various researchers (Fornell 1992; Lee, Lee \& Feick 2001; Oliver 1999) agree that customer loyalty could be accomplished by delivering exceptional value, which result from providing excellent services and quality products (Parasuraman \& Grewal 2000:169; Yang \& Peterson 2004:800).

\section{Experience}

Bowman and Ambrosini (2000:2) stated that tourists will spend their money on products or services that they believe will maximise the satisfaction that they will experience during their stay. A bad experience, on the other hand, where for example a visitor feels he or she is being "ripped off" by paying a large amount extra for parking could decrease the overall satisfaction of the total experience. Research done by Du Plessis (2002:99) refers to the quality of the experience that the destination provides contributes to a destinations global competitiveness, which in turn provides a value for money experience. 


\section{Amenities}

The tourist facilities are those elements of tourism products which do not necessarily provide the motivation for tourist visiting the tourism product, but the absence of which may discourage the tourists from travelling to enjoy the attraction and accommodation. (Das, Sharma, Mohapatra \& Sarkar, 2007:112; Mangion, Durbarry \& Sinclair, 2005:56). Amenities as an important factor for value for money should receive attention in the management plan by providing quality accommodation, roads (accessibility), shops and souvenirs emphasise a value-for-money experience (Du Plessis \& Saayman, 2015:439). Porter (1990:37) also found than amenities such as special features plays a role in value for money perceptions.

\section{Event attributes}

George (2004:208) further suggests that physical evidence is a critical factor when consumers want value for money. Examples of the physical evidence include trained staff, technological advances and hygienic facilities. In the case of events attributes such as the location of the event, product attributes and the changes in this products like the product performance, quality and availability (Flint, Woodruff \& Gardial, 1997:166). Van Zyl and Strydom (2007:121) shows that when describing an arts festival it is necessary to look at the different attributes namely 'festival brands', ticket prices', 'entertainment activities' and 'transport to and from venues'. According to van Zyl (2008:132) the quality of music is also important and personal safety is one of the aspects that will either be a motivation to travel to a place or to not travel to a place.

Keller and Bieger (2006:20) summarise these sentiments by stating the following: "Destinations which have managed to maintain a high level of attractiveness over a long period, in other words, being sustainable, are generally those which offer a highly satisfactory and often unique experience, a quality which is maintained, albeit often at a high price, but which to the market they serve, represents value for money."

If the derived benefits are greater than what is being paid for, tourists perceive high value in the purchase and experience positive consumer value that in turn leads to a definite purchase intention (Chiang \& Jang, 2007:53; Oh, 2000). It can be concluded that value for money is not achieving the lowest price but, rather, it is defined as the optimum combination of total costs and quality. In other words, obtaining the maximum benefits from the resources available through a combination of economy, efficiency and effectiveness (Beaver \& Pye, 2009:18). Chen and Chen (2010:30) contend that it has been agreed that perceived quality and monetary price are the two main antecedents of perceived value of tourism services, amongst various other factors.

To understand the dimension of factors contributing to value for money it is necessary to understand where value for money fits in with value typologies. Although earlier researchers such as Monroe (1979) and Gallarza and Saura (2006) distinguish between acquisition in opposition to transaction value differences and the hedonic opposed to utility separation of value (Holbrook \& Hirschman, 1982; Gallarza \& Saura, 2006) it was the work of Sweeney and Soutar (2001) that differentiated between four value dimensions: emotional value, social value and two types of functional value (price / value for money and performance / quality) (Table 1).

\section{Table 1: The PERVAL scale}

\begin{tabular}{l|l}
\hline $\begin{array}{l}\text { Value Description } \\
\text { Emotional value }\end{array}$ & $\begin{array}{l}\text { The perceived utility through the } \\
\text { creation or perpetuation of feelings or } \\
\text { affective states. }\end{array}$ \\
\hline Social value & $\begin{array}{l}\text { The perceived utility through the } \\
\text { association with positively or } \\
\text { negatively stereotyped demographic, } \\
\text { socio-economic and cultural-ethnic } \\
\text { groups. }\end{array}$ \\
\hline $\begin{array}{l}\text { Functional value } \\
\text { (price/ value for } \\
\text { money) }\end{array}$ & $\begin{array}{l}\text { The utility derived from the product } \\
\text { due to the reduction of its perceived } \\
\text { short term and long term costs. }\end{array}$ \\
\hline $\begin{array}{l}\text { Functional value } \\
\text { (performance/ } \\
\text { quality) }\end{array}$ & $\begin{array}{l}\text { The utility derived from the perceived } \\
\text { quality and expected performance of } \\
\text { the product. }\end{array}$ \\
\hline
\end{tabular}

Source: Sweeney and Soutar (2001:211)

Sweeney and Soutar (2001:216) explain how the research reveals that multiple value dimensions explain consumer choice better, both statistically and qualitatively. Although this research has been used in recent value literature as the basis of discussions, it seems to be relative when one looks at the results of various studies (Du Plessis \& Saayman, 2015; Singh 2011:1) that highlight the impact of external factors, such as the economic climate and the delivery of different tourism products. The challenge for managers and marketers, though, lies in the ability to analyse the external environment to provide the right factors or products at the right time to visitors, which results in the latter's perception of receiving value for their money and ensures return visits or loyal consumption of a particular product. These benefits may include factors such as quality of food, clean facilities, the quality of the infrastructure, the quality of the entertainment, variety of food, suitability, delivery, ability to purchase souvenirs and experiencing special effects, to mention only a few (Du Plessis \& Saayman, 2014:7; Smith \& Colgate, 2007:9). The mix of these and other factors and the degree to which tourists perceive these factors as benefits will differ between tourists at a specific tourism destination and will vary on a case by case basis (Haarhoff, 2007:411). This was evident in the research carried out by Du Plessis and Saayman (2015) on the different factors identified in diverse tourism products. Respondents indicated that performance quality was the most important factor of value for money at a live music performance and the experience of a nature based product. Both of these studies were conducted in the South African tourism industry and highlight the importance of undertaking specific research into a product. 
It is anticipated that this research might confirm the importance of an integrated specialised management and marketing approach focusing on the unique tourism product.

\section{Method of research}

The method of research used is discussed under the following headings: study focus, the questionnaire, sample and the statistical analysis.

\section{Study focus}

To achieve the study goal, a survey was conducted in cooperation with the management of the KKNK. This national arts festival, held annually, as mentioned, in South Africa (Kruger, 2009:15; Saayman, Saayman \& Slabbert, 2009:9) over the Easter holidays in Oudtshoorn, is one of three national arts festivals.

\section{The questionnaire}

A questionnaire was designed to collect the data needed for the study; it was based on the work of Weaver et al. (2007); Petrick (2002); Sweeney and Soutar (2001) and Saayman \& Snyman (2005). Section A focussed on the demographic profile of the respondents and consisted of closed- and openended questions. More specifically, demographic variables consisted of the following: Gender, year born, home language, occupation, province of residence, type of accommodation used, tickets purchased for shows and the attendance at other festivals. Section B measured the value for money factors for the festival on a 5-point Likert Scale where the respondents needed to indicate how the 24 attributes contributed to value for money where: $1=\mathrm{No}$ opinion, 2=No extent, 3=Some extent, 4=Large extent and $5=$ Great extent. The purpose of this study is to determine the factors that contribute to value for money at the Klein Karoo National Arts Festival and the influence of demographic attributes on the assessment of value for money factors.

\section{Sample}

The data was collected between the $31^{\text {st }}$ of March 2012 and the $7^{\text {th }}$ of April 2012, using a quantitative approach. Selfadministered questionnaires were distributed at the KKNK in Oudtshoorn by trained fieldworkers. Stratified sampling was applied to the festival. The different strata were identified according to the most populated festival areas, such as the festival's main area and selected festival venues to enhance the representativeness of the data. Seven hundred questionnaires were evenly distributed between the strata of which 600 were successfully completed and 530 useable in this study.

\section{The statistical analysis}

The data was captured using Microsoft $\odot$ Excel $\odot$ and analysed using SPSS (SPSS Inc, 2010). The analysis was performed in three stages: descriptive analysis of the data, an exploratory factor analysis, followed by correlations between the value factors and selected demographic and festival behaviour variables by means of $t$-tests and ANOVAS. Firstly, a descriptive analysis was carried out on the demographic profile of the respondents of the KKNK. Secondly, a principal axis factor analysis, using an Oblimin rotation with Kaiser Normalisation, was performed on the 24 value for money items to explain the variance-covariance structure of a set of variables through a few linear combinations of these variables. The Kaiser-Meyer-Olkin measure of sampling adequacy was used to determine whether the covariance matrix was suitable for factor analysis. Kaiser's criteria for the extraction of all factors with eigenvalues larger than one were used, since they were considered able to explain a significant amount of variation in the data (Field, 2009).

All items with a factor loading of greater than 0.3 were considered as contributing to a factor (Steyn, 2000). Any item that cross-loaded on two factors of which both were greater than 0.3 , was categorised in the factor where interpretability was best. A reliability coefficient (Cronbach's alpha) was computed for each factor to estimate its internal consistency. All factors with a reliability coefficient above 0.6 were considered as acceptable in this study. The average inter-item correlations were also computed as another measure of reliability; these, according to Clark and Watson (1995) should be between 0.15 and 0.55 . Thirdly, independent $t$-tests and chi-square tests were used to investigate any significant differences between the value for money factors and selected demographic and behavioural variables. The study made use of demographic variables (gender and age) and behavioural variables (length of stay, number of tickets purchase, and average spending, when the decision to visit was made) to examine whether there were statistically significant differences between the groups. The results of the statistical analyses are discussed in the next section.

\section{Results}

The section provides insights into the demographic profile of respondents, the value for money factors as well as the factors influencing value for money perceptions.

\section{Profile of respondents to the Klein Karoo National Arts Festival}

It is evident from Table 2 that both Afrikaans males and females participated in the study. These respondents were on average 42 years of age and living mainly in the home province of the festival, namely the Western Cape. Respondents occupied professional positions but were also self-employed, pensioners and in administrative posts. This profile correlates with the previous research undertaken indicating the same profile for visitors to this festival (Erasmus et al., 2010; Slabbert, Saayman, Viviers, Botha, 2013; Slabbert, Saayman, Viviers, Botha, 2012); therefore these respondents' opinion regarding value for money is important so that adaptions and/or changes can be effected for future festivals. 
Table 2: Demographic profile of respondents

\begin{tabular}{l|c|c}
\hline \multicolumn{1}{c}{$\begin{array}{c}\text { Demographic } \\
\text { characteristics }\end{array}$} & Category & Percentage \\
\hline \multirow{2}{*}{ Gender } & Male & $43 \%$ \\
\cline { 2 - 3 } & Female & $57 \%$ \\
\hline \multirow{2}{*}{ Home language } & Afrikaans & $94 \%$ \\
\cline { 2 - 3 } & English & $5 \%$ \\
\cline { 2 - 3 } & Other & $1 \%$ \\
\hline Age & Average age & 42 years \\
\hline Province of residence & Western Cape & $59 \%$ \\
\cline { 2 - 3 } & Gauteng & $10 \%$ \\
\cline { 2 - 3 } & Eastern Cape & $19 \%$ \\
\cline { 2 - 3 } & Other provinces & $12 \%$ \\
\hline Occupation & Professional & $18 \%$ \\
\cline { 2 - 3 } & Self-employed & $13 \%$ \\
\cline { 2 - 3 } & Pensioners & $13 \%$ \\
\cline { 2 - 3 } & Administrative & $10 \%$ \\
\hline
\end{tabular}

Value for money factors for Klein Karoo National Arts Festival

The factor analysis in Table 3 revealed four factors labelled as effectiveness, experience, amenities as well as quality and price. These factors directly contribute to perceptions of value for money as regards the festival. In this study it was found that effectiveness can be considered as the most important contributing factor to value for money perceptions $(\bar{x}=3.9)$ followed by experience $(\bar{x}=3.8)$. The least important contributing aspect was amenities $(\bar{x}=2.7)$ which include facilities for children, parking and souvenirs as well as the price of the souvenirs. It is also evident from the results that quality and price are not the most important contributing factor to value for money $(\bar{x}=3.3)$. Respondents thus considered effectiveness in terms of festival management, infrastructure and technical aspects as very important. Added to this, the total event experience, atmosphere, venues and services also contribute significantly to value for money perceptions. To a certain extent these can be considered as intangible aspects of the festival, which are more difficult to manage and control, but they nevertheless influence perceptions that directly guide current and future festival behaviour.

\section{Table 3: Value for money factors}

\begin{tabular}{|c|c|c|c|c|}
\hline Factors & Experience & Effectiveness & Amenities & Quality \& price \\
\hline \multicolumn{5}{|l|}{ Experience } \\
\hline Total event experience & .818 & & & \\
\hline The total experience offered by the festival & .791 & & & \\
\hline Variety of food & .729 & & & \\
\hline Atmosphere & .689 & & & \\
\hline Venue / Location & .663 & & & \\
\hline Quality of services offered by festival staff & .609 & & & \\
\hline Quality of the food and beverages & .563 & & & \\
\hline It is a once-in-a-lifetime experience & .434 & & & \\
\hline \multicolumn{5}{|l|}{ Effectiveness } \\
\hline Quality of the infrastructure & & .921 & & \\
\hline Quality of the technical aspects of the shows & & .900 & & \\
\hline Festival management effectiveness & & .750 & & \\
\hline Personal safety & & .592 & & \\
\hline Price of the tickets & & .471 & & \\
\hline Level of hygiene conditions & & .430 & & \\
\hline \multicolumn{5}{|l|}{ Amenities } \\
\hline Exchange rate, in the case of foreigners & & & .880 & \\
\hline Availability of facilities for children & & & .856 & \\
\hline Availability of souvenirs & & & .682 & \\
\hline Price of the souvenirs & & & .619 & \\
\hline Parking cost & & & .454 & \\
\hline \multicolumn{5}{|l|}{ Quality And price } \\
\hline Price of the accommodation & & & & .882 \\
\hline $\begin{array}{l}\text { Quality of the accommodation used during } \\
\text { the trip }\end{array}$ & & & & .842 \\
\hline Price of food and beverages & & & & .651 \\
\hline Transport cost & & & & .470 \\
\hline Quality of the productions & & & & .461 \\
\hline Cronbach Alpha & 0.893 & 0.899 & 0.819 & 0.795 \\
\hline Inter-item correlations & 0.512 & 0.597 & 0.476 & 0.439 \\
\hline Mean values & $3.8(0.91)$ & $3.9(0.95)$ & $2.7(1.07)$ & $3.3(1.01)$ \\
\hline
\end{tabular}

KMO: 0.926

Variance explained: $64 \%$ explained

Bartlett's test of sphericity was significant 
Socio-demographic and festival behaviour factors influencing value for money perceptions

The socio-demographic and festival behaviour factors that influence the perceptions of value for money were determined by means of Spearman Rank Order Correlations (Table 4).

In terms of socio-demographic variables, the analyses firstly revealed that gender does not exert an influence on the value for money perceptions. Males and females assessed these factors in the same manner. Secondly, the analyses revealed that the number of nights spent at the festival $(\mathrm{p}<0.41)$ as well as the average spending of visitors $(p<0.29)$ influenced respondents' assessment of experience. When visitors stay more nights at the festival and spend more money during their stay they tend to rate the experience higher and thus more important. These are also the loyal festinos and for them, attention is needed in terms of the total event experience, including aspects such as variety of food, atmosphere at the festival and location.

Table 4: Factors influencing value for money perceptions

\begin{tabular}{|c|c|c|c|c|c|c|c|c|}
\hline Factors & & Age & $\begin{array}{c}\text { Number of } \\
\text { people in } \\
\text { travelling } \\
\text { group }\end{array}$ & $\begin{array}{l}\text { Number of } \\
\text { people } \\
\text { paying for }\end{array}$ & $\begin{array}{l}\text { Number } \\
\text { of nights }\end{array}$ & $\begin{array}{c}\text { Number } \\
\text { of tickets } \\
\text { bought }\end{array}$ & $\begin{array}{c}\text { Number } \\
\text { of years } \\
\text { visited }\end{array}$ & $\begin{array}{l}\text { Average } \\
\text { spending }\end{array}$ \\
\hline \multirow[t]{3}{*}{ Experience } & $\begin{array}{l}\text { Correlation } \\
\text { Coefficient }\end{array}$ & .074 & -.055 & .040 & $.096^{*}$ & .091 & .000 & $.102^{*}$ \\
\hline & Sig. (2-tailed) & .101 & .227 & .379 & .041 & .055 & .992 & .029 \\
\hline & $\mathrm{N}$ & 489 & 493 & 489 & 457 & 443 & 402 & 455 \\
\hline \multirow[t]{3}{*}{ Effectiveness } & $\begin{array}{l}\text { Correlation } \\
\text { Coefficient } \\
\end{array}$ & $.117^{* * *}$ & -.026 & $.098^{*}$ & .091 & $.156^{* * *}$ & .006 & $.140^{* * *}$ \\
\hline & Sig. (2-tailed) & .009 & .563 & .031 & .053 & .001 & .908 & .003 \\
\hline & $\mathrm{N}$ & 489 & 493 & 489 & 457 & 443 & 402 & 455 \\
\hline \multirow[t]{3}{*}{ Amenities } & $\begin{array}{l}\text { Correlation } \\
\text { Coefficient }\end{array}$ & -.027 & .081 & $.151^{* * *}$ & .080 & -.041 & -.024 & .060 \\
\hline & Sig. (2-tailed) & .551 & .074 & .001 & .089 & .386 & .637 & .204 \\
\hline & $\mathrm{N}$ & 489 & 493 & 489 & 457 & 443 & 402 & 455 \\
\hline \multirow[t]{3}{*}{$\begin{array}{l}\text { Quality and } \\
\text { price }\end{array}$} & $\begin{array}{l}\text { Correlation } \\
\text { Coefficient }\end{array}$ & $.106^{*}$ & .012 & .052 & $.198^{* * *}$ & $.096^{*}$ & .018 & $.134^{* *}$ \\
\hline & Sig. (2-tailed) & .019 & .791 & .249 & .000 & .044 & .725 & .004 \\
\hline & $\mathrm{N}$ & 489 & 493 & 489 & 457 & 443 & 402 & 455 \\
\hline
\end{tabular}

Secondly, it was evident that age $(\mathrm{p}<0.009)$, number of people paying for $(\mathrm{p}<0.031)$, number of tickets bought $(\mathrm{p}<0.001)$ and average spending $(\mathrm{p}<0.003)$ influenced respondents' view of effectiveness. Respondents rated effectiveness as more important when they were older, paying for more people, bought more tickets and spent more at the festival. If respondents were therefore responsible for payments at the festival they regarded quality of infrastructure, technical quality at the festival, safety and pricing as factors contributing to value for money.

Thirdly, group size influenced amenities $(\mathrm{p}<0.001)$ and became more important as the group size increased. Bigger groups consequently consider availability of facilities for children, availability of souvenirs and the pricing thereof as important. Fourthly, age $(\mathrm{p}<0.019)$, number of nights spent $(\mathrm{p}<0.000)$, number of tickets bought $(\mathrm{p}<0.044)$ and average spending $(\mathrm{p}<0.004)$ influenced visitors' perceptions of quality and price. Older respondents, those who stayed longer at the festival, those who bought more tickets and spent more, were influenced by price and quality of accommodation, price of food and beverages as well as transport costs.

\section{Findings and implications}

This section presents the four findings which led to the following four implications:

Firstly, in relation to the literature review (Du Plessis \& Saayman, 2015) it was clear that value for money at festivals is not always directly related only to quality and price as primary factors since this variable resulted in the second lowest mean of all the factors. The experience at and effectiveness of the festival are more important value for money factors (Bowman \& Ambrosini, 2000:2; George, 2004:208). These are more difficult to manage and the festival's staff contributes directly to these factors. High standards should therefore be maintained when creating a festival atmosphere, serving food, choosing venues and trained friendly staff as mentioned by Van Zyl and Strydom (2007:121). Festinos value quality infrastructure, technical quality and safety, which should be planned well in advance and with the needs of the visitors in mind. This type of information should be communicated to the festival goers, enabling them to see the effort from festival management in adhering to their needs.

Secondly, it was found that frequency of visits to the festival did not influence perception of value for money. A possible explanation for this is that respondents might be used to what 
is offered by the festival and also seem to be satisfied with the product offered as was also the case in the research of Du Plessis and Saayman (2015) that focussed on mega events. Festival management should, however, persevere in providing value for money experiences, thereby encouraging return visits to this festival.

Thirdly, it was evident that socio-demographic variables and festival behaviour variables definitely influence visitors' perceptions of value for money. The loyal festinos who stay longer and buy more tickets value effectiveness. Festival management should highlight the quality of the festival in terms of shows, technical aspects, infrastructure and safety and provide value-added packages to these festinos. Visitors who stay longer and spend more considered the experience as an important value for money factor. For this group of festinos, festival management and marketers should emphasise the general festival aspects such as food, atmosphere and location of the festival that was also indicated as important by Fodness (1994); Kozak (2002) and Yoon and Uysal (2005). Older respondents, those staying longer, those who bought more tickets and spent more considered quality and price as an important value for money factor. It is clear that these respondents consider pricing and quality in the decisions they make; hence one should consider attracting them with special offers, value-added packages and membership of a loyalty club. Older respondents' expectations, in terms of effectiveness and quality and price, are higher than those of younger respondents, and this might be due to their level of experience in terms of travel and their level of exposure to festivals.

Lastly, value for money perceptions are not only related to pricing; the functioning of the festival is important. If festivals are to improve their value for money offering, they should first focus on festival effectiveness and festival experience, followed by festival quality and price and festival amenities. These are thus not features that festival management can promise, but are factors that they should deliver on.

\section{Conclusions}

The purpose of this research was to determine whether sociodemographic variables influence the perceptions, as regards value for money, of visitors to the KKNK. It was evident that value for money is important to festinos, being influenced by various socio-demographic and festival variables. Specifically, age, number of people paid for, number of tickets bought, average spending, number of nights stayed, influence perceptions of value. It is clear that the older and more loyal visitors consider effectiveness and experience as important factors. These factors should be embedded in marketing plans, development plans and the overall image of the festival. The most significant contribution of this research is that quality and price was not the most important value for money factor in a festival context. Instead, effectiveness and experience were emphasised as the two most important factors. Festivals should thus ensure easy access to the festival on different levels, a quality offering in terms of the programme and affordable prices for all activities as these ultimately result in high value for money perceptions. Perception of value for money does not function in isolation but it is clearly influenced by other variables; therefore festivals should follow an integrated management approach.

\section{Acknowledgements}

The authors would like to acknowledge outside reviewers of their drafts and the National Research Fund for funding that supported the research.

\section{References}

Beaver, P. \& Pye, C. 2009. The meaning of value-for-money. [online] URL:http://www.contention.org

Bowman, C. \& Ambrosini, V. 2000. 'Value creation versus value capture: Towards a coherent definition of value in strategy', British Journal of Management, 11: 1-15.

Cant, M. 2005. The importance of price, In Cant, C., Brink, A. \& Machado, R. (Eds). Pricing management. Claremont, South Africa: New Africa Books. pp. 1-14.

Chan, J.K.L. \& Baum, T. 2007. 'Motivation factors of ecotourists in ecolodge accommodation: The push and pull factors', Asia Pacific Journal of Tourism Research, 12(4): 349-364.

Chen, C. \& Chen, F. 2010. 'Experience quality, perceived value, satisfaction and behavioral intentions for heritage tourists', Tourism Management, 31: 29-35.

Chiang, C. \& Jang, S. 2007. 'The effects of perceived price and brand image on value and purchase intention: leisure travellers' attitudes towards online hotel booking', Journal of Hospitality and Leisure Marketing, 15(3): 49-69.

Clark, L.A. \& Watson, D. 1995. 'Constructing validity: Basic issues in objective scale development', Psychological Assessment, 7(3): 309-319.

Cravens, D.W., Holland, C.W., Lamb, C.W. \& Moncrieff, W.M. 1988. 'Marketing's role in product and service quality', Industrial Marketing Management, 17(November): 285-304.

Cronin, J., Brady, M. \& Hult, T. 2000. 'Assessing the effects of quality, value and customer satisfaction on consumer behavioural intentions in service environments', Journal of Retailing, 76(2): 193-218.

Das, D., Sharma, S.K., Mohapatra, P.K.J. \& Sarkar, A. 2007. 'Attractiveness of Varanasi as a tourist destination: Perspective of foreign tourists', International Journal of Tourism Policy, 1(2):111133.

Du Plessis E. 2002. Competitiveness of South Africa as a tourist destination. Potchefstroom: Potchefstroom University of Christian Higher Education. (Unpublished Master's dissertation)

Du Plessis, E. \& Saayman, M. 2015. 'The relationship between value for money, motives and experience of tourists to the Kruger National Park', Journal of Contemporary Management, 12: 426446. 
Du Plessis, E. \& Saayman, M. 2015. 'Understanding value for money at a live music performance', Journal of Contemporary Management, 11: 1-19.

Erasmus, L.J.J., Saayman, M., Saayman, A., Kruger, M., Viviers, P., Slabbert, E. \& Oberholzer, S. 2010. The socio-economic impact of visitors to the ABSA KKNK in Oudtshoorn 2010. Potchefstroom. Unpublished Report, Institute for Tourism and Leisure Studies.

Erlendsson, J. 2002. Defining value for money: value for money studies in higher education. [online] URL:http://www.hi.is/ ;joner/eaps/wh_vfmhe.htm

Field, A. 2009. Discovering statistics using IBM SPSS statistics. London: Sage.

Flint, P.J., Woodruff, R.B. \& Gardial, S.F. 1997. 'Customer value change on industrial marketing relationships', Industrial Marketing Management, 26:163-175.

Fodness, D. 1994. 'Measuring tourist motivation', Annals of Tourism Research, 21(3), 555-581.

Fornell, C. 1992. 'A national customer satisfaction barometer: The Swedish experience', Journal of Marketing, 56(1): 6-21.

Gallarza, M.G. \& Saura, I.G. 2006. 'Value dimensions of perceived value, satisfaction and loyalty: An investigation of university students' travel behaviour', Tourism Management, 27(2006): 437452.

George, R. 2004. Marketing South African tourism. 2nd ed. New York: Oxford.

Haarhoff, R. 2007. An analysis of the price competitiveness of South Africa as an international tourist destination. Bloemfontein: Central University of Technology. (Unpublished DTech Thesis.)

Holbrook, M.B. \& Hirschman, E.C. 1982. 'The experiential aspects of consumption: consumer fantasies, feelings and fun', Journal of Consumer Research, 9, 132-140.

Huang, B. \& Yang, Y. 2011. Measuring rural tourism value for money: The experience economy of leisure agriculture in Central Taiwan. [online] URL:http://ieeexplore.ieee.org/stamp/stamp.jsp? tp=\&arnumber $=5999233$

Kainth, J.S. \& Verma, H.V. 2011. 'Consumer perceived value: construct apprehension and its evolution', Journal of Advanced Social Research, 1(1): 20-57.

Keller, P. \& Bieger, T. 2006. Marketing efficiency in tourism: coping with volatile demand. Dunfermline: Eruch Schmidt Verslag.

Khan, M.W.A. 2011. Value for money audit is a true sense of resources and this is the part of consultancy services. [online] URL:http://wakbs.blogspot.com/2011/03/value-for-money-vfmaudit-is-true-sense.html

Kirkpatrick, D. 2009. The meaning of value-for-money. [online] URL:http://www.contention.org

Kitshoff, H. 2004. 'Klein Karoo Nasionale Kunstefees (KKNK) Oudtshoorn, 3-11 April 2004', South African Theatre Journal, 18: 64-80.
Kozak, M. 2002. 'Comparative analysis of tourist motivations by nationality and destinations', Tourism Management, 23(3): 221-232.

Kruger, M. 2009. Spending behaviour of visitors to the Klein Karoo National Arts Festivals. Potchefstroom: North-West University. (M.Com. Dissertation) 66 p.

Kruger, M., Saayman, M. \& Ellis, S.M. 2010. 'Does loyalty pay? First-time versus repeat visitors at a national arts festival', Southern African Business Review, 14(1): 79-104.

Lee, J., Lee, J. \& Feick, L. 2001. 'The impact of switching costs on the customer satisfaction-loyalty link: Mobile phone service in France', Journal of Services Marketing, 15(1): 35-48.

Lovelock, C.H. 2000. Service marketing. (4th ed.). Upper Saddle River, NJ: Prentice Hall International.

Mangion, M.L., Durbarry, R. \& Sinclair, M.T. 2005. 'Tourism competitiveness: Price and quality', Tourism Economics, 11(1): 4568.

Monroe, K.B. 1979. Pricing, making profitable decisions. New York: McGraw-Hill Management.

Monroe, K.B. 1990. Pricing: making profitable decisions. (2nd ed.). New York: McGraw-Hill Book Company.

Oh, H. 2000. 'The effect of brand class, brand awareness and price on customer value and behaviour intentions', Journal of Hospitality and Tourism Research, 24(2): 136-162.

Oliver, R.1. 1999. 'Fundamental issues and directions for marketing', Journal of Marketing, 63: 33-44

Parasuraman, A. \& Grewal, D. 2000. 'The impact of technology on the quality-value-loyalty chain: A research agenda', Journal of the Academy of Marketing Science, 28(1): 168-174.

Petrick, J.F. 2002. 'Experience uses history as a segmentation tool to examine golf travellers' satisfaction, perceived value and repurchase intentions', Journal of Vacation Marketing, 8(4): 332 342 .

Porter, M.E. 1990. Competitive advantage of nations. New York: Free Press.

Saayman, M. 2003. A marketing analysis of tourists visiting Kgalagadi Transfrontier and Augrabies Falls National Parks in South Africa. Potchefstroom: Institute for Tourism and Leisure Studies. $61 \mathrm{p}$.

Saayman, M., Saayman, A. \& Slabbert, E. 2009. 'Who spends and who does not: Clustering visitors at a national arts festival', South African Journal of Business Management, 42(1): 9-16.

Saayman, M. \& Snyman, J.A. 2005. Entrepreneurship tourism style. Potchefstroom, South Africa: Institute for Tourism and Leisure Studies.

Seymour, K. 2012. The perceived value of scuba diving tourists at a marine destination. North-West University. (Unpublished Master's Dissertation).

Singh, J. 2011. Make your money count when you buy something. [online] URL:http://www.dailynews.co.tz 
Slabbert, E., Saayman, A., Viviers, P. \& Botha, K. 2012. The socioeconomic impact of visitors to the ABSA KKNK in Oudtshoorn. TREES: Potchefstroom.

Slabbert, E., Saayman, A., Viviers, P. \& Botha, K. 2013. The socioeconomic impact of visitors to the ABSA KKNK in Oudtshoorn. TREES: Potchefstroom.

Smith, J.B. \& Colgate, M. 2007. 'Customer value creation: A practical framework', Journal of Marketing Theory and Practice, 15(1): 7-23.

Sweeney, J.C. \& Soutar, G.N. 2001. 'Consumer perceived value: The development of a multiple item scale', Journal of Retailing, 77: 203-220.

SPSS Inc. 2010. SPSS R -16.0 for Windows, [online] URL:www.spss.com

Steyn, H.S. 2000. 'Practical significance of the difference in means', South African Journal of Industrial Psychology, 26(3): 1-3.

Tait, M. 2009. Understanding customers. In Boshoff, C. \& Du Plessis F. (Eds.). Services marketing: a contemporary approach. Cape Town, South Africa: Juta. pp. 89-112.

Van Zyl, C. 2008. 'A conjoint analysis for successfully positioning of selected arts festivals in South Africa', Southern African Business Review, 12(3): 128-155.

Van Zyl, C. \& Strydom, J.W. 2007. 'The use of game theory to determine the optimum market position of selected arts festivals in South Africa', South African Business Review, 11(3): 121-143.

Weaver, P.A, Weber K. \& McCleary K.W. 2007. 'Destination evaluation: The role of previous travel experience and trip characteristics', Journal of Travel Research, 45(3): 333-334.

Yang, Z. \& Peterson, R.T. 2004. 'Customer perceived value, satisfaction and loyalty: The role of switching costs', Psychology and Marketing, 21(10): 799-822.

Yoon, Y. \& Uysal, M. 2005. 'An examination of the effects of motivation and satisfaction on destination loyalty: A structural model', Tourism Management, 26(1): 45-56. 